\title{
On the Causes of the Minor Dry Season over the Coastal Region of the Northern Gulf of Guinea
}

\author{
Angora Aman, Elisee Toualy*, Fidele Yoroba \\ UFR SSMT, Laboratory of Atmospheric Physic and Fluid Mechanics, Felix Houphouet-Boigny University of Cocody, Abidjan, \\ Cote d'Ivoire \\ Email: *elisee.toualy@gmail.com
}

How to cite this paper: Aman, A., Toualy, E. and Yoroba, F. (2018) On the Causes of the Minor Dry Season over the Coastal Region of the Northern Gulf of Guinea. Atmospheric and Climate Sciences, 8, 121-133.

https://doi.org/10.4236/acs.2018.82009

Received: January 8, 2018

Accepted: February 20, 2018

Published: February 23, 2018

Copyright () 2018 by authors and Scientific Research Publishing Inc. This work is licensed under the Creative Commons Attribution International License (CC BY 4.0).

http://creativecommons.org/licenses/by/4.0/

\begin{abstract}
Along the littoral shelf of northern coast of the Gulf of Guinea (GG), a minor dry season of the rainfall regime is concomitantly observed with the occurrence of a major coastal upwelling in July-August-September (JAS). It was then supposed that this upwelling drives that minor dry season. But no previous studies have tried to understand this minor dry season and, this study is the first focusing on this question. The investigations undertaken to explain this dry season on the Ivorian littoral shelf with the ERA-Interim data from the European Centre for Medium Range Weather Forecasts over the 19802016 period have shown that the minor dry season is driven by the Northward migration of the Inter Tropical Convergence Zone (ITCZ) during this period and, enhanced by the occurrence of the major coastal upwelling of the northern GG at the same time. These two phenomena interact as follow: i) the ITCZ is located in JAS far in the north cutting off convective processes along the coast, ii) the air on the coastal region is poor in humidity, iii) the air temperature on the bordering region of the GG is cooled by the coastal upwelling to value less than $26^{\circ} \mathrm{C}$ and not favorable for providing convection.
\end{abstract}

\section{Keywords}

Dry Season, West African Monsoon, Gulf of Guinea, Coastal Upwelling, Convective Rainfall

\section{Introduction}

The bordering countries of northern coast of Gulf of Guinea (Figure 1) undergo two rainy seasons: The major one is observed during April-July period with a peak in June. During this period the Intertropical Convergence Zone (ITCZ) is located at $5^{\circ} \mathrm{N}$ [1] [2] [3] [4] [5]. The minor rainy season takes place from September 


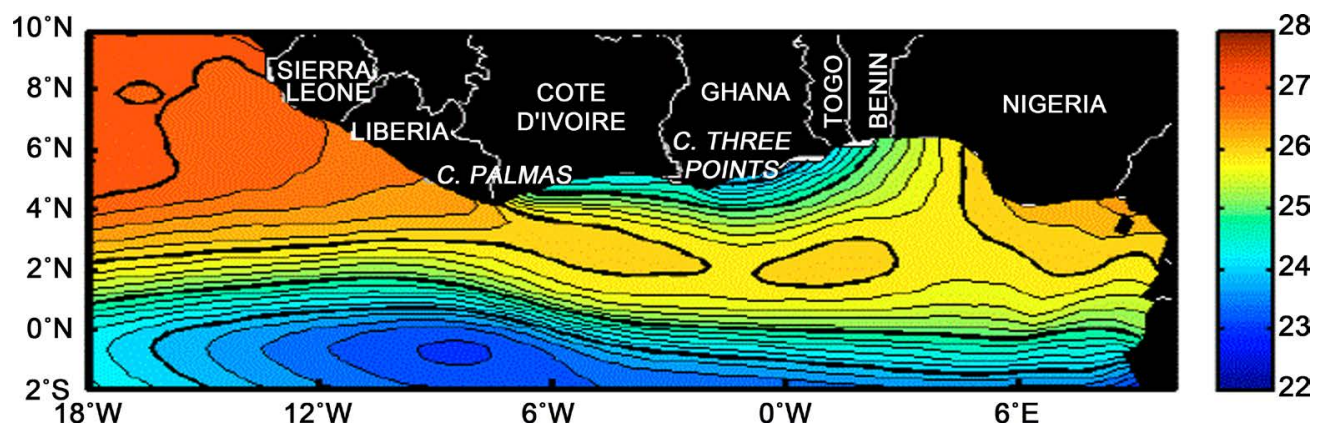

Figure 1. Sea Surface Temperature in the Gulf of Guinea (Courtesy, Toualy et al., 2012). The two regions of weak temperatures represent respective the Atlantic Cold Tongue (ACT) and the coastal upwelling north of the Gulf of Guinea.

to November with a peak in October [6] [7] when the ITCZ migrates southward. The minor and major dry seasons are respectively observed in July-AugustSeptember [8] and, in December-January-February-March [8].

The economy of these countries is highly dependent of Agriculture fully controlled by the rainfall regime. Rainfall variability could induce both floods and droughts and, negatively affects human lives also. Therefore understanding the temporal and spatial variability of the rainfall regime in this region is very important for the population. Two seasonally phenomena occurring in the Gulf of Guinea (GG) could represent the key factors for understanding the variability of the precipitation along the northern coast of the GG: the West Africa Monsoon (WAM) and the coastal upwelling.

The WAM is a large-scale circulation in the lower atmosphere transporting moisture from the Atlantic Ocean to the West African land. The WAM occurs annually between April and September when highest amount of humidity is transported towards the coast. The variability of the moisture fluxes, associated convergence, and rainfall is strongly impacted by the Atlantic Cold Tongue (ACT) described by Caniaux et al. [9] and the Saharan heat-low [5]. The onset of the coastal rainfall in April due to the WAM is a consequence of the acceleration of low-level cross-equatorial southerly winds, important for establishing the cold tongue, inhibiting convection near the equator and, transporting moisture towards the coast [5]. The complex interactions between the WAM fluxes and the continental land surface conditions [10], oceanic conditions [6] [9] [11] [12] and, atmospheric circulation [13] [14] drive therefore most of the annual rainfall in this region. Particularly, the annual rainfall variability on the continental land in the northern coast of the GG is controlled by the WAM [5].

A seasonal upwelling occurs along the northern coast of the GG during two periods of the year [15] [16] [17] [18]. A minor season of coastal upwelling takes place in boreal winter from December to March. The major season of the coastal upwelling north of the GG is observed in boreal summer from July to September. The SST is weak during this period from $30^{\circ} \mathrm{C}$ to almost $25^{\circ} \mathrm{C}-24^{\circ} \mathrm{C}$ for some years leading to a cooling of $-5^{\circ} \mathrm{C}$ over few months. The minimum values of SST during the major season of upwelling are observed in August. During the 
season of major coastal upwelling and particularly in August, Bakun [15] observed an important reduction of rainfall along the coast face to the oceanic region recording strongest cooling. It was then supposed that this coastal upwelling could influence the rainfall over the bordering land [3] [6] [18] through its impact on the lower layer circulations of the Atmosphere [19] [20]. However, there are few works that investigated the impact of this upwelling on the minor drought season. Therefore this question remains still opened.

The aim of this study is to try to understand the minor dry season over the littoral shelf, in other word, is this minor dry season driven by the major coastal upwelling, which occurs at the same period? The atmospheric reanalysis afford the opportunity to have the different components of the rainfall (Convective and Stratiform) and dynamics parameters at hourly to monthly scales over the entire world. These datasets from the European Reanalysis ERA-Interim (ERA-I) have been used through this study over the 1980-2016 period. This work is presented as follow; section 2 presents the data used. Results and discussion are shown respectively in the sections 3 and 4. Finally, we summarize in section 5 the important results of this work and, perspectives are given.

\section{Material}

The data used for this study are from 1980 to 2016 and, are global data covering simultaneously the ocean and the land. In West Africa, in situ data coverage is very poor; therefore we turn to reanalysis data, which afford to make available global data at continuous time scale through sophisticated combination of in situ measurements and model outputs. The data used combine: (i) the total precipitation, the stratiform and convective precipitations to investigate their temporal and spatial variability; (ii) The flux of specific humidity, Sea Surface Temperature, air temperature and, horizontal components of the wind to understand the influence of both the atmospheric and oceanic variability on the minor dry season along the northern coast of GG. These data have been produced by the European reanalysis ERA-I and retrieved freely at this address https://www.ecmwf.int/en/forecasts/datasets/reanalysis-datasets/era-interim. The ERA-I is a reanalysis of meteorological homogeneous observations and numerical model outputs produced by the European Centre for Medium Range Weather Forecasts (ECMWF) to overcome the lack of data in some regions and also the inhomogeneities related to model and data assimilation [21]. These data assimilated high observation data coming from space borne instruments [22] combined to model outputs through sophisticated methods and, automated bias corrected [23].

In this study, monthly average rainfall of daily means outputs characterized by a spatial resolution of $50 \mathrm{Km}$ between two consecutive grid points are used. The units of these data are in meter and, we convert them in millimeter. The other data have the same time and spatial scales as precipitation data. The wind component, air temperature and, specific humidity are obtained at different pressure level from the surface $(1000 \mathrm{hPa})$ to $200 \mathrm{hPa}$. 
The ERA-I precipitations data have been validated and used in many regions such as in England [24] and, in the Tropical Pacific [25] and for the entire world [26]. To tackle this study, a validation effort of the ERA-I rainfall data has been done based on the Global Precipitation Climatology Project (GPCP) data [27] [28] [29]. The ERA-I total precipitation data have been averaged over the 1980-2016 period and, bilinearly interpolated using Climate Data Operator software to fit the spatial grid of GPCP data. Figure 2 shows the climatology of GPCP presenting observation data, the climatology of total precipitation from ERA-I data and the bias between GPCP and ERA-I data. The maximum rainfall amounts are observed in the same areas both in the GPCP and in the ERA-I data (Figure 2). The minimum precipitation is observed north of $10^{\circ} \mathrm{N}$. The precipitations are reduced until the Sahara both in these two datasets. But, the ERA-I precipitations are underestimated compared to GPCP data with some positive biases in the area of mountains recording highest quantity of precipitation due to convective lines. Negative differences are also observed in Cote d'Ivoire, Nigeria and Ghana. Differences between these datasets in the area of Cote d'Ivoire and Ghana are insignificant. Then, ERA-I precipitations represent quasi-well the rainfall variability in this region and are appropriate for our investigation.

\section{Results}

\subsection{Seasonal Variability of the Sea Surface Temperature and Precipitation}

The Sea Surface Temperature (SST) is an important key of the oceanic conditions for the WAM [5] [9] [11]. The monthly climatology of ERA-I SST (Figure 3) depicts two cold pools in the GG. The first one of large spatial extension with

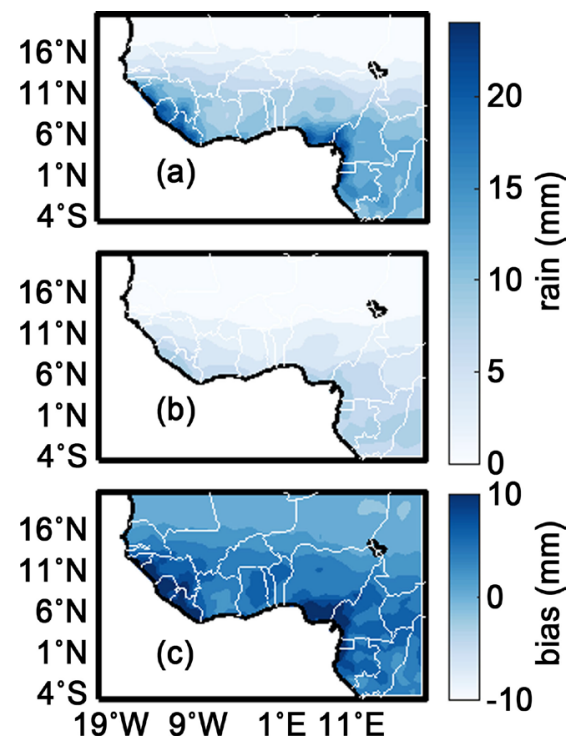

Figure 2. Climatology of the precipitation from GPCP (panel a), ERA-Interim (panel b) and, the bias (panel c) estimated as the difference between GPCP and ERA-Interim data of the 1980-2016 period. The ERA-Interim data has been interpolated to fit the spatial grid of GPCP data. Unit is $\mathrm{mm}$ and intervals between contours are $1 \mathrm{~mm}$. 

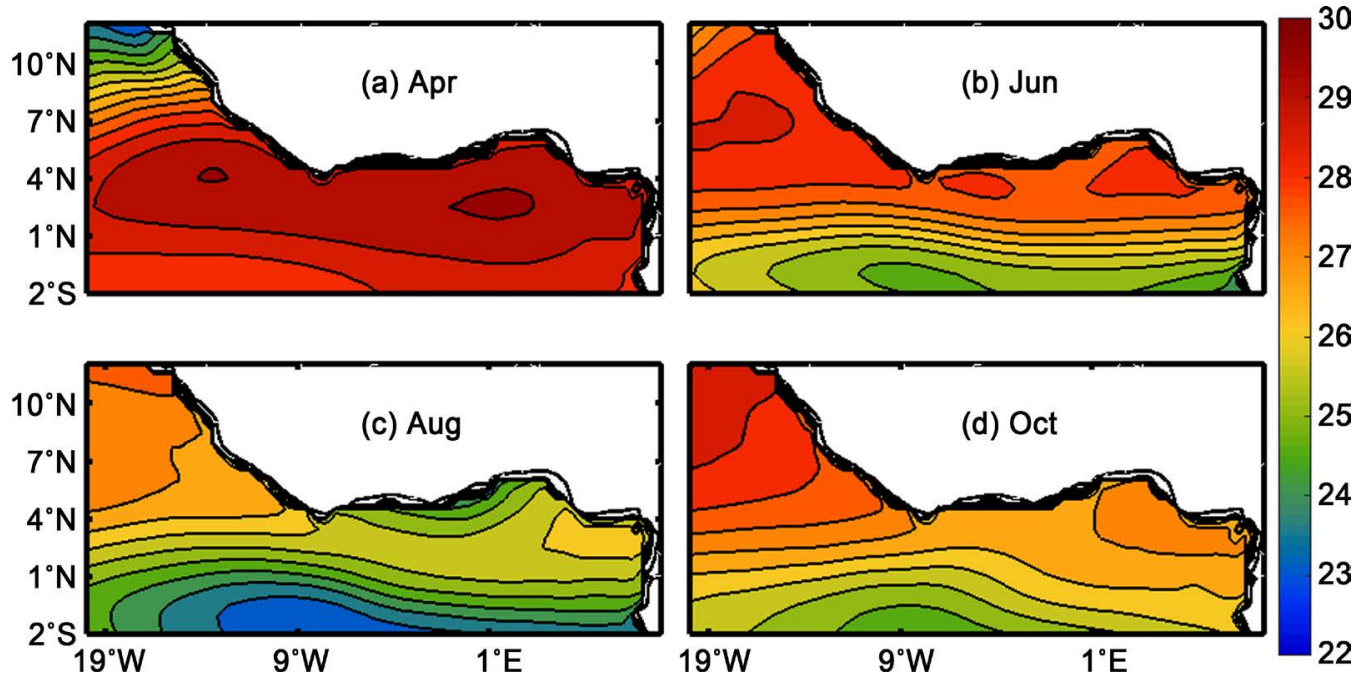

Figure 3. Spatial distribution of the monthly climatology of Sea Surface Temperature. The monthly means of SST have been retrieved for the individual months and averaged to form the climatology of April (panel a), June (panel b), August (panel c) and October (panel d) of the 1980-2016 period. Intervals between contours are $0.5^{\circ} \mathrm{C}$.

minimum SST reaching $22^{\circ} \mathrm{C}$ is observed between $5^{\circ} \mathrm{S}$ and $2^{\circ} \mathrm{N}$ (June and August, panels b and c) and, represents the ACT. The second one of minor spatial extension and weaker intensity (minimum SST around $24^{\circ} \mathrm{C}$ ) compared to the ACT is confined to the northern coast and, is the signature of the coastal upwelling (August, panel c). At the coast, SSTs have been cooled from $30^{\circ} \mathrm{C}$ (maximum value) in April to $24^{\circ} \mathrm{C}$ in August.

Figure 4(a) shows the climatology of air temperature at the surface (1000 $\mathrm{hPa}$ ). The air temperature in the surface layers of the atmosphere is very important for the dynamic of the marine atmosphere boundary layer. The temperature at the first level $(1000 \mathrm{hPa})$ is commonly used to represent the value at the surface. Air temperatures at the surface are very high on the land north of $12^{\circ} \mathrm{N}$ with values reaching $40^{\circ} \mathrm{C}$ at $20^{\circ} \mathrm{N}$. The minimum temperatures are observed South of $12^{\circ} \mathrm{N}$ in August with minimum values less than $25^{\circ} \mathrm{C}$ in coastal area over Cote d'Ivoire and on the Ocean. In April, the temperatures are around $30^{\circ} \mathrm{C}$ South of $12^{\circ} \mathrm{N}$ until the Ocean. These maximum values in April spread over the entire region of Cote d'Ivoire and Ghana. Values around $28^{\circ} \mathrm{C}-29^{\circ} \mathrm{C}$ are observed on the coastal area in June while the North of $12^{\circ} \mathrm{N}$ is warmer than the coastal area. The zonal mean of air temperature in the box $\left[7^{\circ} \mathrm{W}-3^{\circ} \mathrm{W}\right]$ clearly shows that the temperature is weak, less than $25^{\circ} \mathrm{C}$ on the coastal area when the upwelling is strong (Figure 4(b)).

Total Precipitations (TP) have been averaged for the respective months April, June, August and October to build the monthly climatology of rainfall over the 1980-2016 period (Figure 5). The maximum rainfall amounts are observed in April, June and, also in October at the coast. Minimum values are observed in August at the coast, while they are maximum in the north during the same month. Maximum precipitations are observed first at the coast in April, May and 


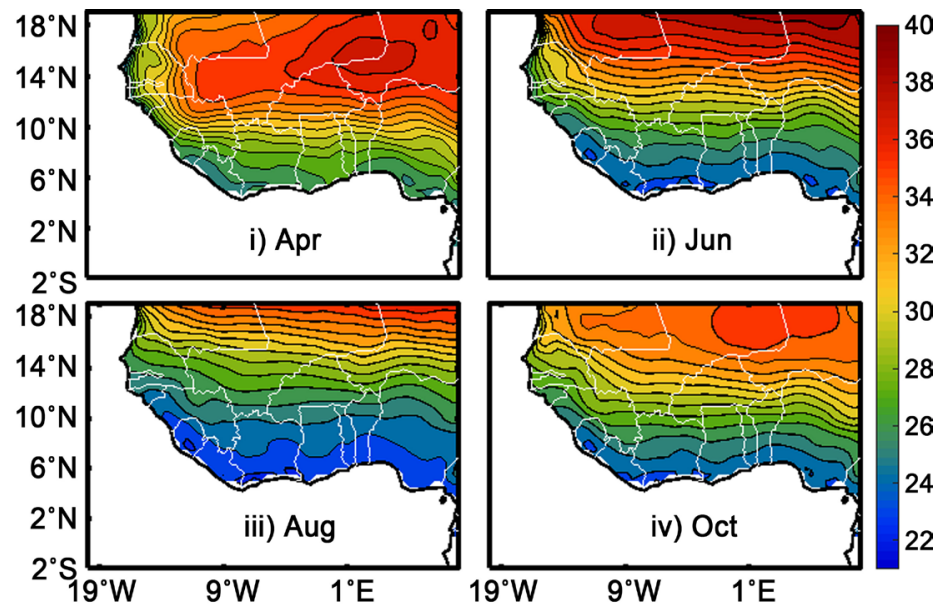

(a)

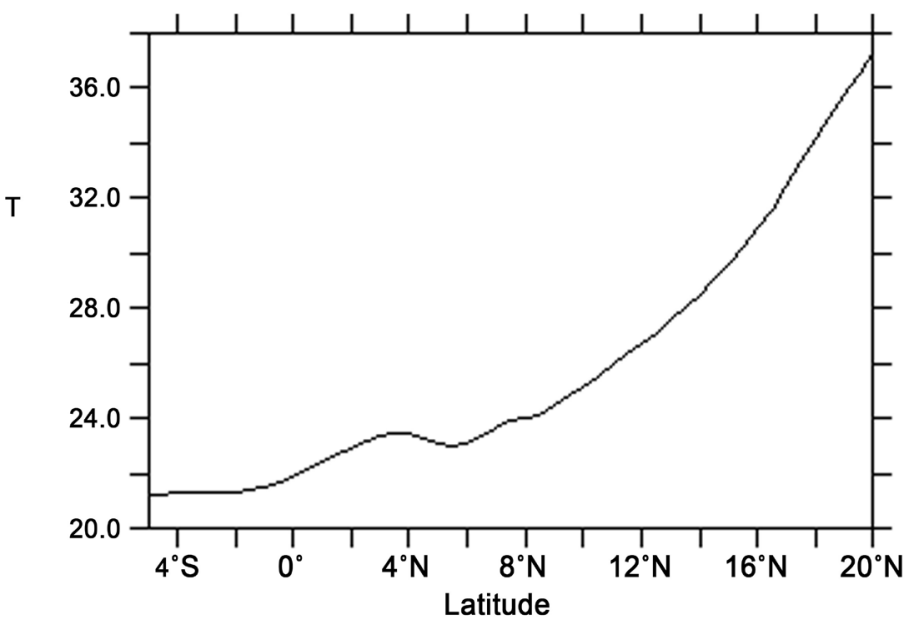

(b)

Figure 4. (a) As in Figure 3 but for air temperature at the surface ( $1000 \mathrm{hPa})$; (b) zonal mean in the box [ $\left.7^{\circ} \mathrm{W}-3^{\circ} \mathrm{W}\right]$ of monthly climatology of surface air temperature in August of the 1980-2016 period.
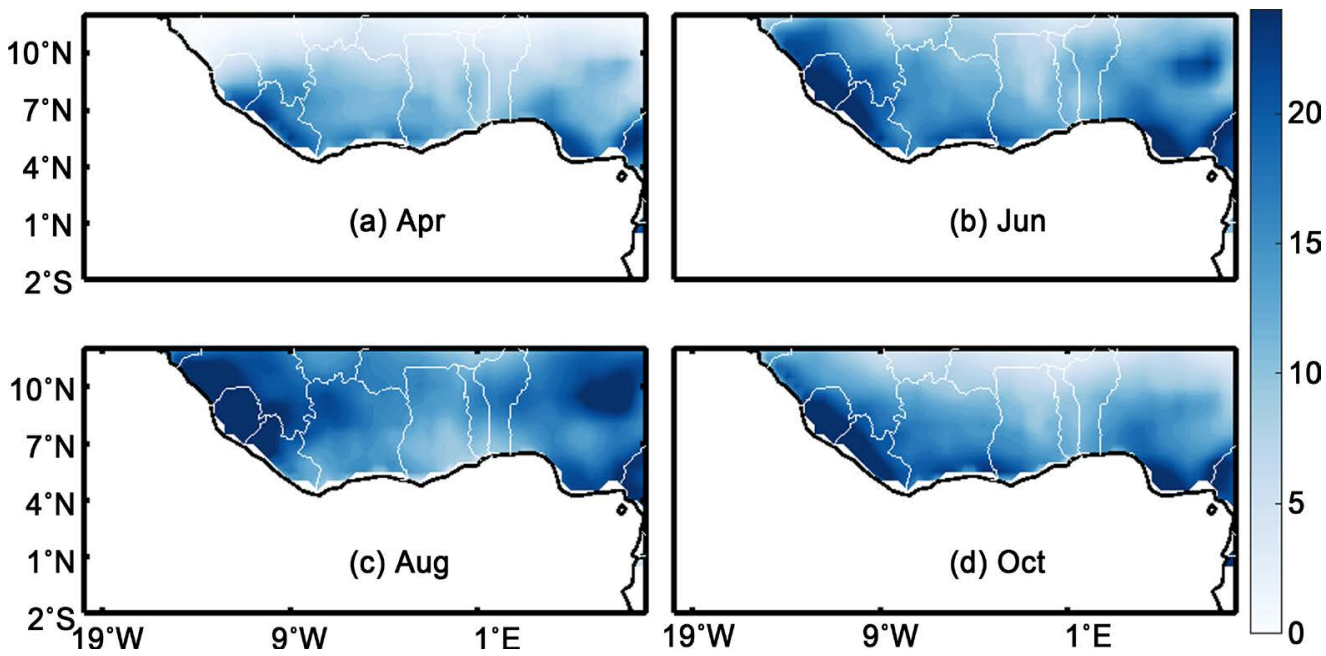

Figure 5. Spatial distribution of the monthly climatology of the total precipitation amount. The monthly means of rainfall have been retrieved for the individual months and averaged to form the climatology of April (panel (a)), June (panel (b)), August (panel (c)) and, October (panel (d)) of the 1980-2016 period. Intervals between contours are $0.5 \mathrm{~mm}$ and Units are in $\mathrm{mm}$. 
June before spreading northward in the other months. When the maximum precipitations are extending northward, they start decreasing along the coast until their minimum values are reached in August (Figure 5).

Several steps in the mean latitudinal displacement of the ITCZ corresponding to the different rainy seasons in West Africa are depicted in Figure 5. The Cloud convection impacts (Figure 5) appear on the coastal zone (i.e. $4^{\circ} \mathrm{N}$ ) from March and persist until June with appearance of maximum precipitation. From June, the band of strong precipitation migrates towards the north latitudes and remains quasi-stationary between $8^{\circ} \mathrm{N}$ and $12^{\circ} \mathrm{N}$ with strong convective precipitations at $10^{\circ} \mathrm{N}$ and, then retreats towards the coastal regions. This phenomenon called monsoon "jump" is well known and was long studied by Sultan and Janicot [1] over West Africa. The position of the ITCZ during the monsoon period varies between $5^{\circ} \mathrm{N}$ and $10^{\circ} \mathrm{N}$ from May to July, when maximum convection energy (CAPE) is available. This jump $\left(5^{\circ} \mathrm{N}\right.$ to $\left.10^{\circ} \mathrm{N}\right)$ marks the onset of rains on the Sahel at the end of June [1] [2].

Moreover, after the monsoon "jump" in late June, the coastal areas are experiencing a small dry season from the end of July to September which coincides with the coastal upwelling manifestation. Indeed, in the northern part of the equator (i.e. $0^{\circ} \mathrm{N}$ ), the seasonal SST cooling of the boreal summer established between Cote d'Ivoire and Benin tends to increase the meridional gradient of the SSTs in the Gulf of Guinea (GG). That suggests a significant influence of this coastal upwelling on the rainfall of coastal areas.

\subsection{Dominant Component of the Rainfall}

The time latitude diagrams of monthly climatology of the convective precipitation and large-scale precipitation have been built for each month to determine, which component dominates the total rainfall amounts (not shown) on the study region (Figure 6). The convective precipitations are higher than the largescale precipitations particularly, at the beginning of the first rainy season. The core of the maximum convective rainfalls migrates northward to reach the northern part of Cote d'Ivoire (north of $8^{\circ} \mathrm{N}$ ) in August. At this period, the convective rainfalls are reduced at the coast.

\subsection{Variability of the Moisture Flux and Surface Wind}

Figure 7 shows the horizontal distribution of surface specific humidity and the vector plot (arrows) of wind at $950 \mathrm{hPa}$ for each month of April, June, August and October. Maximum values of moisture are observed in the GG and on the coastline during April and June. These high quantities of humidity are advected by the Southward winds on the land from April to August when they get their northmost latitude around $16^{\circ} \mathrm{N}-18^{\circ} \mathrm{N}$.

After August, the core of the maximum moisture is retracted back southward to the Ocean (Figure 7). On the coastal area, the amount of moisture is weak during the months of July and August, while the maximum amount during the 


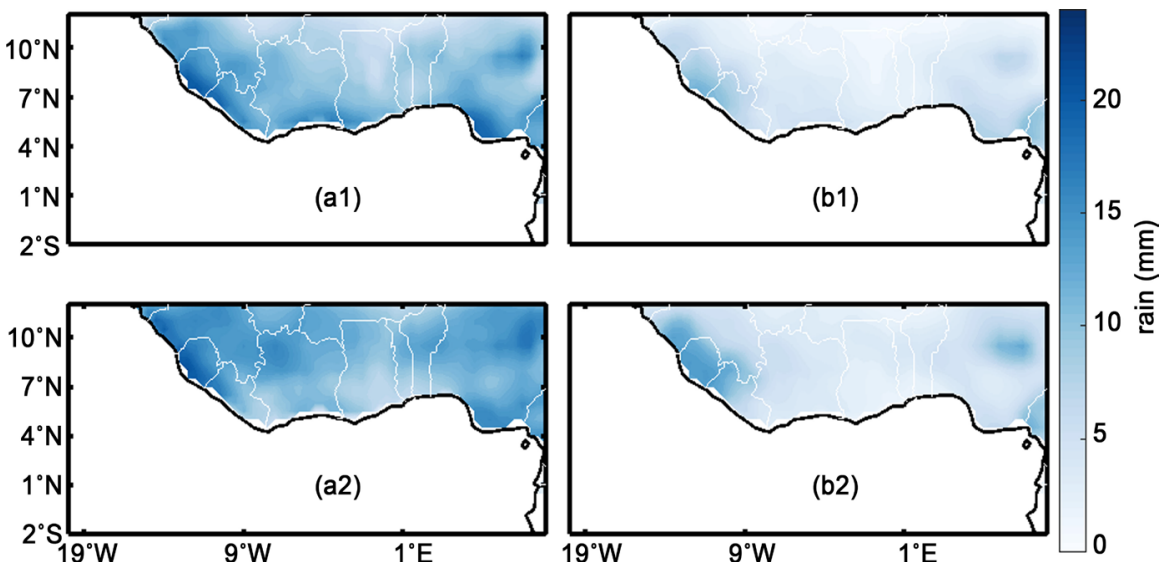

Figure 6. Time-latitude diagrams of the convective precipitation (panel (a)) and large scale precipitation (panel (b)) over the 1980-2016 period. The data have been averaged between $10^{\circ} \mathrm{W}$ and $10^{\circ} \mathrm{E}$. A mean day rainfall value has been computed as the average of the rainfall of the same day for these different years (for example, the day 1 represents the mean for the first January of these 17 years).

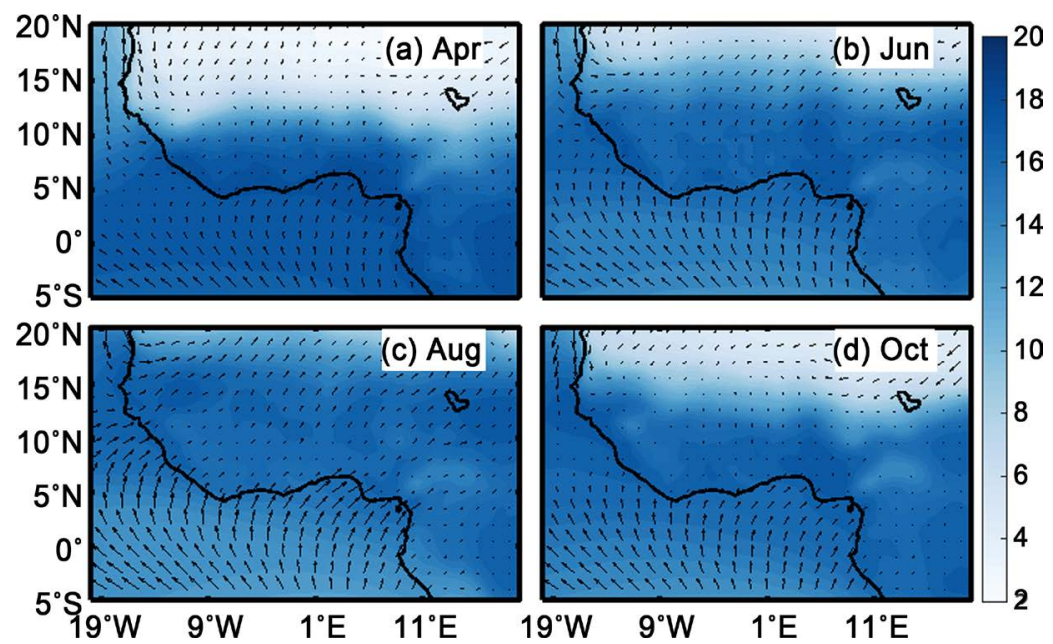

Figure 7. Map of the monthly climatology of specific humidity (shaded) and wind components (vector arrows). The monthly means of surface $(1000 \mathrm{hPa})$ specific humidity and wind components at $975 \mathrm{hPa}$ have been retrieved for the respective months and averaged to form the climatology of April, June, August and October of the 1980-2016 period. Intervals between contours are $0.5 \mathrm{~g} / \mathrm{kg}$ and units are in $\mathrm{mm}$.

same period is observed in the north. On the Ocean, moisture is high during the entire year excepted in July and August. The wind directions are southwest in the GG and north on the northmost land during the entire year. The winds from the South are stronger from April to June. The increasing of the Southward winds pushes the ITCZ on the continent till $18^{\circ} \mathrm{N}$ in June. In addition, when the oceanic wind is maximum from April to June on the land, we observe that the wind is reduced in July-August on the coastal domain from $4^{\circ} \mathrm{N}$ to approximately $8^{\circ} \mathrm{N}$ in Cote d'Ivoire and in Ghana. The wind is higher in July-August north of $8^{\circ} \mathrm{N}$.

The surface $(950 \mathrm{hPa})$ wind speeds are zonally averaged in the box $\left[7^{\circ} \mathrm{W}\right.$ - 


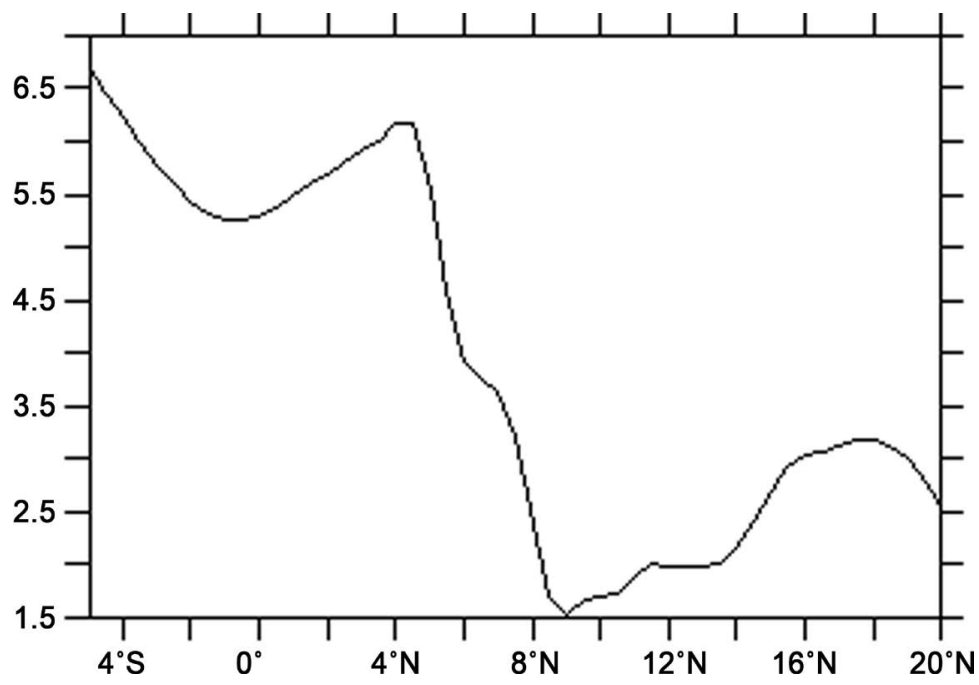

Figure 8. Zonal mean in the box $\left[7^{\circ} \mathrm{W}-3^{\circ} \mathrm{W}\right]$ of monthly climatology of wind speed at $975 \mathrm{hPa}$ in August of the 1980-2016 period.

$3^{\circ} \mathrm{W}$ ] to reinforce the analysis about the decrease of the wind speeds over the cold air in August when the coastal upwelling is very well established (Figure 8). This figure shows an abrupt decline in the wind speeds between $4^{\circ} \mathrm{N}$ and $9^{\circ} \mathrm{N}$. The wind speeds increase after $9^{\circ} \mathrm{N}$ until the location of the ITCZ (Figure 7).

\section{Discussion}

This paper tries to understand the causes of the minor dry season over the littoral shelf of the GG. This minor dry season peaks in August when the ITCZ is located in the North [1] [2] [3] [4] [5] and, when the coastal upwelling of the area is established [15] [16] [17] [19] [20]. The latitudinal displacement of the ITCZ and this coastal upwelling could be then two potential candidates driving this minor dry season. Bakun [15] observed the reduction of the rainfall on the coastal area of Cote d'Ivoire and Ghana during the season of the major coastal upwelling and suggested that this upwelling could trigger this minor upwelling. Besides in this region, this study and thoses of $\mathrm{Gu}$ and Adler [3] shown that rainfall variability is also related to large-scale processes. Then we should not take in account only the coastal upwelling responsible of this minor dry season. For example, in this region, the sea breeze conditions are very important in the understanding of the long dry season [8].

This study showed that rainfall amount during the rainy season is dominated by the convective precipitations as noted in previous studies [3]. The convective precipitations during the monsoon season in this region are essentially driven by the disturbance of the African Easterly Jet (AEJ). The reduction of the amount of convective precipitations in August along the coastline means then some conditions that favour convective activities have changed, i.e., the air temperature, the water vapor, the wind. This period is characterized by minimum SST off the coast [15] and, it is suggested that coastal upwelling is the reason of the precipitation decline along the coast during the peak of the upwelling [6] [15] [18]. 
The meridional SST gradients play an important role in forcing convection [12]. This manisfests as weak air temperature on the ocean and high temperature on the land. The cooling of surface air temperature (Figure 4(a)) on the coastal area of the GG by the coastal upwelling occurring there breaks this meridional gradient and could reduce the convection. The SST/rain correlation found by Kouadio et al. [6] is weak in August and high in September. This SST/rain relationship is different to that of the rainy season and remains in the vicinity of the coast [6]. This relationship is similar to our results.

The reduction of the moisture and the surface wind on the coastal region during the peak of the coastal upwelling are some causes of the shift of convective precipitations over the coastal area. But this decrease of the amount of moisture is not mainly driven by this upwelling but by the reciprocal action between the low pressure of Saint Helena Anticyclone in the Southern Hemisphere and the system of low presssure in northern hemisphere (Açore and Harmattan wind field) as shown in Figure 6. The surface wind flow decreases then over this cold area as a coupling between the ocean and the atmosphere in the form of modification of atmospheric boundary layer explained by Wallace et al. [20] and, observed on the ACT and in the Pacific Ocean [20]. This reduction of the wind field over the coastal domain could reduce the wind shears and inhibit convective movements. To summarize, this study showed that the decrease in the available amount of moisture in July-August combined the decrease of turbulent flow and the presence of cold air temperature less than $26^{\circ} \mathrm{C}$ (critical temperature at which maximum evaporation occurs) [12] could be the mechanism by which the north coastal upwelling of the GG enhances the minor dry drought season over the bordering countries of the GG. This idea has been suggested by $\mathrm{Gu}$ and Adler [3] mentioning that the maximum rainfall along the guinean coast in April is related to the presence of warm SST over the tropical Atlantic while its disappearance is due to the formation of an oceanic cold tongue in this region.

\section{Conclusions}

The investigations on the cause of the minor dry season occurring along the littoral shelf of the northern GG concomitantly with the major coastal upwelling of this region are presented in this paper. Most of the rainfalls over West Africa are the consequence of the WAM. These precipitations are dominated by the convective processes but the large-scale precipitations remain an important component. Over the coastal area, the maximum precipitations are observed from April to June and from October to November during the major and the minor rainy seasons respectively. The major and minor rainy seasons are associated respectively to the first passage of the ITCZ from South to North over coastal region and to the second passage of the ITCZ from North to South. During August, the ITCZ reaches its northmost position providing maximum precipitations north of $10^{\circ} \mathrm{N}$. At this same time, precipitation is reduced in the coastal area leading to 
the dry season.

The combined analyses of SST, air temperature, specific humidity and different wind components show that, when the ITCZ reaches the continent during April-June, SST and air temperature are high and, maximum moisture are transported on the land by strong oceanic winds. These conditions are suitable for the development of strong convective activities and consequently high rain over the coastal region. In August, the cooling of air temperature on the coastal domain by the coastal upwelling could decrease the winds over the coastal area and could also reduce the amount of water vapour. These winds increase north of the region of influence of this upwelling. The coastal upwelling cools SST and air temperature to value less than $26^{\circ} \mathrm{C}$ and not favourable for the development of convective rainfall. Besides the amounts of moisture available are reduced not only by the upwelling but by the fact that the Southward wind are weaken. At this period, the ITCZ is far in the north due to the strong influence of the Saint Helena Anticyclone on the Harmattan wind but not because of the coastal upwelling. So our conclusion is that the coastal upwelling could not be the main cause of the dry season in August in the coastal area as was thought previously. This upwelling provides conditions not favourable for the development of regional convection. Besides as the winds are reduced over the area of influence of this upwelling and are increased more in the north, the upwelling could push far in the north the ITCZ. This Hypothesis should be addressed latter in another study. This study drawn some points that could explain this minor dry season, but could not fully explain the mechanisms behind because of the climatological analysis adopted. A fully study with numerical modeling should address the correlation and interannual analyses.

\section{Acknowledgements}

Some facilities for this study have been provided by the International University of Grand Bassam (Cote d'Ivoire). The authors thank the European Centre for Medium-Range Weather Forecasts for providing freely the ERA-Interim datasets. These data are downloaded at this address https://www.ecmwf.int/en/forecasts/datasets/reanalysis-datasets/era-interim. The authors wish to thank the reviewers for their constructive remarks.

\section{References}

[1] Sultan, B. and Janicot, S. (2000) Abrupt Shift of the ITCZ over West Africa and Intra-Seasonal Variability. Geophysical Research Letters, 27, 3353-3356. https://doi.org/10.1029/1999GL011285

[2] Le Barbé, L., Lebel, T. and Tapsoba, D. (2002) Rainfall Variability in West Africa during the Years 1950-1990. Journal of Climate, 15, 187-202. https://doi.org/10.1175/1520-0442(2002)015<0187:RVIWAD>2.0.CO;2

[3] Gu, G. and Adler, R.F. (2004) Seasonal Evolution and Variability Associated with the West African Monsoon System. Journal of Climate, 17, 3364-3377. https://doi.org/10.1175/1520-0442(2004)017<3364:SEAVAW>2.0.CO;2 
[4] Hagos, S.M. and Cook, K.H. (2007) Dynamics of the West African Monsoon Jump. Journal of Climate, 20, 52-64. https://doi.org/10.1175/2007JCLI1533.1

[5] Thorncroft, C.D., Nguyen, H., Zhang, C. and Peyrillé, P. (2011) Annual Cycle of the West African Monsoon: Regional Circulations and Associated Water Vapour Transport. Quarterly Journal of the Royal Meteorology Society, 137, 129-147. https://doi.org/10.1002/qj.728

[6] Kouadio, Y., Ochou, D.A. and Servain, J. (2003) Tropical Atlantic and Rainfall Variability in Cote d'Ivoire. Geophysical Research Letters, 30, 1-4. https://doi.org/10.1029/2002GL015290

[7] Yoroba, F., Diawara, A., Kouadio, K.Y., Schayes, G., Assamoi, A.P., Kouassi, K.B., Kouassi, A.A. and Toualy, E. (2011) Analysis of the West African Rainfall Using a Regional Climate Model. International Journal of Environmental Sciences, 1, 1335-1349.

[8] Cautenet, S. and Rosset, R. (1989) Numerical Simulation of Sea Breezes with Vertical wind Shear during Dry Season at Cape of Three Points, West Africa. Monthly Weather Review, 117, 329-339. https://doi.org/10.1175/1520-0493(1989)117<0329:NSOSBW>2.0.CO;2

[9] Caniaux, G., Giordani, H., Redelsperger, J-L., Guichard, F., Key, E. and Wade, M. (2001) Coupling between the Atlantic Cold Tongue and the West African Monsoon in Boreal Spring and Summer. Journal of Geophysical Research, 116, C04003. https://doi.org/10.1029/2010JC006570

[10] Wang, G. and Eltahir, E.A.B. (2000) Ecosystem Dynamics and the Sahel Drought. Geophysical Research Letters, 27, 795-798. https://doi.org/10.1029/1999GL011089

[11] Fontaine, B., Trazaska, S. and Janicot, S. (1998) Evolution of the Relationship between Near and Global and Atlantic SST Modes and the Rainy Season in West Africa: Statistical Analyses and Sensitivity Experiments. Climate Dynamics, 14, 353-368. https://doi.org/10.1007/s003820050228

[12] Tompkins, A.M. (2001) On the Relationship between Tropical Convection and Sea Surface Temperature. Journal of Climate, 14, 633-637. https://doi.org/10.1175/1520-0442(2001)014<0633:OTRBTC>2.0.CO;2

[13] Nicholson, S.E. and Grist, J.P. (2001) A Conceptual Model for Understanding Rainfall Variability in the West African Sahel on Interannual and Interdecadal Timescales. International Journal of Climatology, 21, 1733-1757. https://doi.org/10.1002/joc.648

[14] Diedhiou, A., Janicot, S., Viltard, A. and De Felice, P. (1998) Evidence of Two Regimes of Easterly Waves over West Africa and Tropical Atlantic. Geophysical Research Letters, 25, 2805-2808. https://doi.org/10.1029/98GL02152

[15] Bakun, A. (1987) The Guinea Current Upwelling. Nature, 271, 147-150. https://doi.org/10.1038/271147a0

[16] Picaut, J. (1983) Propagation of the Seasonal Upwelling in the Eastern Equatorial Atlantic. Journal of Physical Oceanography, 13, 18-37. https://doi.org/10.1175/1520-0485(1983)013<0018:POTSUI>2.0.CO;2

[17] Toualy, E., Stanojevic, G., Kouadio, K.Y. and Aman, A. (2012) Multi-Decadal Variability of Sea Surface Temperature in the Northern Coast of Gulf of Guinea. Asian Journal of Applied Sciences, 5, 552-562. https://doi.org/10.3923/ajaps.2012.552.562

[18] Ali, K.E., Kouadio, K.Y., Zahiri, E.P., Aman, A., Assamoi, A.P. and Bourles, B. (2011) Influence of the Gulf of Guinea Coastal and Equatorial Upwellings on the Precipitations along Its Northern Coasts during the Boreal Summer Period. Asian Journal of Applied Sciences, 4, 271-285. https://doi.org/10.3923/ajaps.2011.271.285 
[19] Chilton, D.B., Esbensen, S.K., Schlax, M.G., Thum, N., Freilich, M.H., Wentz, F.J., Gentemann, C.L., McPhaden, M.J. and Schopf, P.S. (2001) Observations of Coupling between Surface Wind Stress and Sea Surface Temperature in the Eastern Tropical Pacific. Journal of Climate, 14, 1479-1498. https://doi.org/10.1175/1520-0442(2001)014<1479:OOCBSW >2.0.CO;2

[20] Wallace, J.M., Mitchell, T.P. and Deser, C. (1989) The Influence of Sea Surface Temperature on Surface Wind in the Eastern Equatorial Pacific: Seasonal and Interannual Variability. Journal of Climate, 2, 1492-1499. https://doi.org/10.1175/1520-0442(1989)002<1492:TIOSST >2.0.CO;2

[21] Semedo, A., Suselj, K., Rutgersson, A. and Sterl, A. (2011) A Global View on the Wind Sea and Swell Climate and Variability from ERA-40. Journal of Climate, 42, 1461-1479. https://doi.org/10.1175/2010JCLI3718.1

[22] Dee, D.P., Uppala, S.M., Simmons, A.J., Berrisford, P., Poli, P., Kobayashi, S., Andrae, U., Balmaseda, M.A., Balsamo, G., Bauer, P., Bechtold, P., Beljaars, A.C.M., Van de Berg, L., Bidlot, J., Bormann, N., Delsol, C., Dragani, R., Fuentes, M., Geer, A.J., Haimberger, L., Healy, S.B., Hersbach, H., Holm, E.V., Isaksen, L., Kallberg, P., Kohler, M., Matricardi, M., McNally, A.P., Monge-Sanz, B.M., Morcrette, J.J., Park, B.K., Peubey, C., De Rosnay, P., Tavolato, C., Thepaut, J.N. and Vitart, F. (2011) The ERA-Interim Reanalysis: Configuration and Performance of the Data Assimilation System. Quarterly Journal of the Royal Meteorological Society, 137, 553-597. https://doi.org/10.1002/qj.828

[23] Dee, D.P. and Uppala, S. (2009) Variational Bias Correction of Satellite Radiance Data in the ERA-Interim Reanalysis. Quarterly Journal of the Royal Meteorological Society, 135, 1830-1841. https://doi.org/10.1002/qj.493

[24] De Leeuw, J., Methven, J. and Backburn, M. (2014) Evaluation of ERA-Interim Reanalysis Precipitation Products Using England and Wales Observations. Quarterly Journal of the Royal Meteorological Society, 141, 798-806. https://doi.org/10.1002/qj.2395

[25] Pfeifroth, U., Mueller, R. and Ahrens, B. (2013) Evaluation of Satellite-Based and Reanalysis Precipitation Data in the Tropical Pacific. Journal of Applied Meteorology and Climatology, 52, 634-644. https://doi.org/10.1175/JAMC-D-12-049.1

[26] Di Giuseppe, F., Molteni, F. and Dutra, E. (2013) Real-Time Correction of ERA-Interim Monthly Rainfall. Geophysical Research Letters, 40, 3750-3755. https://doi.org/10.1002/grl.50670

[27] Huffman, G.J., Adler, R.F., Arkin, P., Chang, A., Ferraro, R., Gruber, A., Janowiak, J., McNab, A., Rudolf, B. and Schneider, U. (1997) The Global Precipitation Climatology Project (GPCP) Combined Precipitation Dataset. Bulletin of the American Meteorological Society, 78, 5-20. https://doi.org/10.1175/1520-0477(1997)078<0005:TGPCPG>2.0.CO;2

[28] Huffman, G.J., Adler, R.F., Bolvin, D.T. and Gu, G. (2009) Improving the Global Precipitation Record: GPCP Version 2.1. Geophysical Research Letters, 36, LI17808. https://doi.org/10.1029/2009GL040000

[29] Adler, R.F., Huffman, G.J., Chang, A., Ferraro, R., Xie, P.P., Janowiak, J., Rudolf, B., Schneider, U., Curtis, S., Bolvin, D., Gruber, A., Susskind, J., Arkin, P. and Nelkin, E. (2003) The Version-2 Global Precipitation Climatology Project (GPCP) Monthly Precipitation Analysis (1979-Present). Journal of Hydrometeorology, 4, 1147-1167. https://doi.org/10.1175/1525-7541(2003)004<1147:TVGPCP >2.0.CO;2 